\title{
Risk and protective factors associated with being bullied on school property compared with cyberbullied
}

\author{
Ray M. Merrill ${ }^{*}$ and Carl L. Hanson
}

\begin{abstract}
Background: We identified bullying victimization (bullied on school property versus cyberbullied) by selected demographic, personal characteristic, and behavior variables.

Methods: A cross-sectional analysis was conducted on adolescents $(n=13,583)$ completing the 2013 Youth Risk Behavior Survey (YRBS) in grades 9 through 12.

Results: Being bullied on school property in the past 12 months was significantly more common in females than males, in earlier school grades, and in Whites and other racial groups compared with Blacks and Hispanics. Being bullied on school property generally decreased with later school grades, but cyberbullying in the past 12 months remained constant. Being bullied on school property or cyberbullied was significantly positively associated with mental health problems, substance use, being overweight, playing video games for 3 or more hours per day, and having asthma. The association was greatest with having mental health problems. Cyberbullying was generally more strongly associated with these conditions and behaviors. Protective behaviors against bullying victimization included eating breakfast every day, being physically active, and playing on sports teams. Those experiencing victimization on school property and cyberbullying were significantly more likely to experience mental health problems compared with just one of these types of bullying or neither.

Conclusions: Cyberbullying victimization is generally more strongly associated with mental health problems, substance use, being overweight, playing video games for 3 or more hours per day, and having asthma than bullying victimization on school property. However, because bullying on school property is more common in grades 9-11, this form of bullying has a greater burden on these conditions and behaviors in these school grades.
\end{abstract}

\section{Background}

Recent adolescent suicides and school shootings have received heightened publicity and raised awareness regarding the growing public health problem of bullying. Bullying is prevalent and often has detrimental effects on individuals, families, and communities [1]. While definitions of bullying vary, most researchers agree it involves targeted intimidation or humiliation [2], and includes (1) aggressive and intentionally abusive behavior towards another that (2) persists over time, and (3) consists of an imbalance of power between the perpetrator and victim [3-7]. Although bullying occurs among young children and adults, the majority of research

\footnotetext{
* Correspondence: Ray_Merrill@byu.edu

Department of Health Science, College of Life Sciences, Brigham Young University, 2063 Life Sciences Building, Provo, Utah 84602, USA
}

focuses on adolescents in schools [2]. Studies report that approximately 10-30\% of adolescents are involved as bullies, victims, or both bullies and victims [4], which is consistent throughout the United States [8], Europe [9, 10], Latin America [11-13], and Australia [14].

Being a victim of bullying can be classified as direct or indirect $[15,16]$. Direct forms of bullying consist of physical attack and/or verbal harassment, whereas indirect forms of bullying involve social exclusion, spreading rumors and other related, passive-aggressive actions [7, 15, 17-19]. In other words, direct forms of bullying involve intimidating, humiliating, or belittling, whereas indirect forms seek to destroy an individual's social reputation and/or status while concealing the identity of the perpetrator [2]. Numerous studies confirm that direct confrontation does not progress to indirect forms of 
bullying with age [20]. Cyberbullying is viewed as an extension of traditional bullying and includes the use of electronic or digital media by individuals or groups to communicate hostile or aggressive text messages or emails, embarrassing pictures and rumors posted on social networking sites, and distorted profiles intended to inflict harm or discomfort on others [21]. It differs from traditional forms of bullying in that the aggressor often remains anonymous [22].

Bullying among adolescents can have adverse effects on the victims in terms of distress, as well as subsequent deviant behaviors and possible persistent psychiatric problems [9, 14, 23-25]. For example, one study of sixth, ninth, and twelfth grade students in Minnesota found that $6.1 \%$ reported frequent (weekly in the past 30 days) perpetration only, $9.6 \%$ frequent victimization only, and $3.1 \%$ both, with suicidal thinking for these three groups being $22 \%, 29 \%$, and $38 \%$, respectively [26]. Research has found that bullying victims experience greater levels of fear and worry, disobedience, lying, and irritability [27], as well as higher levels of insecurity, anxiety, and depression [28-31]. Bullying victims tend to internalize behaviors such as depression, anxiety, and social withdrawal while externalizing behaviors such as disruptiveness, dishonesty, and aggression [32, 33].

In an effort to better address bullying victimization, researchers have sought to find the antecedents to victimization by identifying the predictors. These predictors are typically referred to as risk and protective factors and are often assessed in a school setting. Risk factors are behaviors or characteristics that predict a future problem while protective factors are those indicators that reduce or prevent a future problem [34]. Risk and protective factors of bullying victimization may differ according to whether the form of bullying is on school property or cyberbullying through e-mail, chat rooms, instant messaging, websites, or texting.

The purpose of this study was to compare victimization levels of bullying on school property and cyberbullying among students in grades 9 through 12 across selected demographic, personal characteristic, and behavior variables. The association between experiencing mental health problems and the frequency of those problems with being bullied or cyberbullied was also explored. Finally, we will assess the frequency of mental health problems according to combinations of being bullied and/or cyberbullied.

\section{Methods}

\section{Sampling}

The Youth Risk Behavior Surveillance System (YRBSS) monitors health and protective behaviors among youth in the United States, such as mental health, substance use, sexual behavior associated with unintended pregnancy and sexually transmitted infections, body weight, and physical activity/inactivity. The prevalence of obesity and asthma are also monitored. The YRBSS includes the national school-based Youth Risk Behavior Survey (YRBS), administered by the Centers for Disease Control and Prevention (CDC), as well as urban school district school-based YRBSS, administered by state and local education and health agencies. Public and private schools from all 50 states and the District of Columbia are represented in the YRBS.

The sample design involved a three-stage cluster sampling process in order to obtain a nationally representative sample of students attending public and private schools in grades 9 through 12. In the first stage the sampling frame consisted of 1,276 primary sampling units (PSUs), which involved counties, subareas of large counties, and groups of smaller, adjacent counties. From the PSUs, a sample of 54 was taken, based on probability sampling proportional to the overall school enrollment size for the PSU. The second stage of sampling consisted of 193 schools with any grade 9 through 12, based on probability proportional to the size of the school enrollment. The third stage of sampling involved random sampling within each grade, of which one or two classrooms were chosen from a required subject or period. Black and Hispanic students were oversampled. Additional details of the three sampling scheme and the strategies for oversampling Blacks and Hispanics can be found elsewhere [35].

\section{Data collection and questionnaire}

Participation in the survey was anonymous and voluntary. Prior to participating in the survey, parental permission was obtained. Completion of the questionnaire was carried out in a single class period and followed the CDC's Institutional Review Board protocol for the YRBS. The survey takes approximately $40 \mathrm{~min}$ to complete. Students whose parents did not provide consent participated in an alternate reading activity, while their classmates completed the survey. The questionnaire consisted of 86 questions and is available online [36]. Studies have assessed and improved the questionnaires validity and reliability since the surveys inception in 1991 [37]. The anonymous survey was deemed exempt from institutional review board review at Brigham Young University.

\section{Data and response rates}

The 2013 YRBS consists of 13,633 questionnaires from 148 public and private schools, 50 of which failed quality control and were excluded, leaving 13,583 for assessment. Response rates were $77 \%$ for the schools, $88 \%$ for the students, and $66 \%$ overall [38]. Additional details of the data processing procedures and response rates are available elsewhere [38]. 


\section{Variables}

Two outcome variables involved questions about bullying. Prior to asking these two questions on the YRBS, the following statement was made on the instrument: "Bullying is when 1 or more students tease, threaten, spread rumors about, hit, shove, or hurt another student over and over again. It is not bullying when 2 students of about the same strength or power argue or fight or tease each other in a friendly way." The first bullying question asked: "During the past 12 months, have you ever been bullied on school property?" The second bullying question asked: "During the past 12 months, have you ever been electronically bullied? (Count being bullied through e-mail, chat rooms, instant messaging, websites, or texting.)"

Independent variables consisted of demographic variables include age (12 years or younger, 13 years, 14, years, 15 years, 16 years, 17 years, and 18 years or older), sex, race/ethnicity (White, Black or African American, Hispanic/Latino, All other races), and grade (9, 10, 11, 12), and selected mental health, substance use, sexual behavior weight, and other variables shown in Table 3. Race/ethnicity was derived from two questions: (1) "Are you Hispanic or Latino?" (response options "yes" or "no") and (2) "What is your race?" (response options "American Indian or Alaska Native," "Asian," "Black or African American," "Native Hawaiian or other Pacific Islander," or "White).

\section{Statistical assessment}

Cross-tabulations were evaluated using the Rao-Scott chi-square test. Slope coefficients from regression analysis were assessed using the $t$ test. Statistical significance was based on two-tailed hypothesis tests at the 0.05 level. The YRBS employs a complex sampling scheme, which requires that we account for the sampling design (stratification, clustering, and unequal selection probabilities) in order to obtain valid estimates and tests of hypotheses. Analyses were conducted using the Statistical Analysis System, version 9.4 (SAS Institute Inc., Cary, NC, USA, 2012) procedures SURVEYFREQ and SURVEYREG, which are designed to analyze the complex sample survey data correctly; tratum, primary sampling unit, and weight variables were included in the data set and accounted for in the SAS procedures. The weight variable was based on student sex, race/ethnicity, and grade. It was applied to each record to adjust for oversampling of Black and Hispanic students and for school and student nonresponse. The weighted estimates represent all public and private school students in the United States in grades 9 through 12 .

\section{Results}

Being bullied on school property in the past 12 months was significantly more common in females than males, in earlier school grades, and in Whites and other racial groups compared with Blacks and Hispanics (Table 1). Being bullied on school property compared with cyberbullied in the past 12 months was more common in males, grades 9-11, and across the racial/ethnic groups, more so among Blacks and Hispanics. Among males and females, being bullied on school property generally decreased with later school grades, but cyberbullying remained somewhat constant across school grades

Table 1 Bullying Victimization According to Selected Demographic Variables

\begin{tabular}{|c|c|c|c|c|c|c|c|c|c|}
\hline & \multirow[b]{2}{*}{ Weighted Number } & \multirow[b]{2}{*}{ Weighted \% } & \multicolumn{3}{|c|}{$\begin{array}{l}\text { During the past } 12 \text { months, } \\
\text { have you ever been bullied } \\
\text { on school property? }\end{array}$} & \multicolumn{3}{|c|}{$\begin{array}{l}\text { During the past } 12 \text { months, have you ever } \\
\text { been electronically bullied? (Count being } \\
\text { bullied through email, chat rooms, instant } \\
\text { messaging, websites, or texting.) }\end{array}$} & \multirow{2}{*}{$\begin{array}{l}\text { Bullied to Cyber- } \\
\text { bullied Ratio } \\
\text { Ratio }\end{array}$} \\
\hline & & & $\%$ & Estimate & $95 \% \mathrm{Cl}$ & $\%$ & Estimate & $95 \% \mathrm{Cl}$ & \\
\hline \multicolumn{10}{|l|}{ Sex } \\
\hline Male & 88704 & 51.3 & 17.61 & 1.00 & Referent & 9.69 & 1.00 & Referent & 1.82 \\
\hline Female & 84154 & 48.7 & 22.27 & 1.26 & $1.20-1.33$ & 21.57 & 2.26 & $2.04-2.43$ & 1.03 \\
\hline \multicolumn{10}{|l|}{ Grade } \\
\hline $9^{\text {th }}$ & 46795 & 27.1 & 24.56 & 1.75 & $1.61-1.89$ & 15.79 & 1.11 & $1.00-1.23$ & 1.56 \\
\hline $10^{\text {th }}$ & 43948 & 25.5 & 22.02 & 1.57 & $1.45-1.70$ & 16.33 & 1.15 & $1.02-1.28$ & 1.35 \\
\hline $11^{\text {th }}$ & 41331 & 24.0 & 17.60 & 1.25 & $1.14-1.37$ & 15.42 & 1.08 & $0.96-1.22$ & 1.14 \\
\hline $12^{\text {th }}$ & 40394 & 23.4 & 14.05 & 1.00 & Referent & 14.23 & 1.00 & & 0.99 \\
\hline \multicolumn{10}{|l|}{ Race/Ethnicity } \\
\hline White & 107293 & 62.7 & 22.07 & 1.00 & Referent & 17.79 & 1.00 & Referent & 1.24 \\
\hline Black & 23996 & 14.0 & 12.69 & 0.58 & $0.53-0.63$ & 8.81 & 0.50 & $0.44-0.56$ & 1.44 \\
\hline Hispanic/Latino & 24117 & 14.1 & 17.96 & 0.81 & $0.75-0.88$ & 13.19 & 0.74 & $0.66-0.84$ & 1.36 \\
\hline All other races & 15795 & 9.2 & 21.68 & 0.98 & $0.89-1.08$ & 17.25 & 0.97 & $0.85-1.10$ & 1.26 \\
\hline
\end{tabular}


within each racial/ethnic group (Fig. 1). Frequency of being a victim of cyberbullying was more similar to being bullied on school property for females, and even tended to surpass it in grades 11 and 12 for Whites and other racial groups.

Being a victim of bullying within each school grade was greatest in the most common age in that grade, for both bullied on school property and cyberbullying (Table 2). Yet the age immediately younger than the most common age within each grade had a much higher level of bullying victimization than the age immediately older than the most common age. Within each grade, there is no consistent pattern across age in the ratio of being bullied compared with cyberbullied, with the exception of the ratio being greatest in the age group just prior to the most common age.

Being bullied on school property in the past 12 months was significantly greater across the mental health, substance use, weight, and asthma variables, more so for the mental health variables (Table 3). Among the sexual behavior variables, only having had sex before 13 years of age was significantly, positively associated with bullying victimization. Playing video games $3+$ hours per day was also positively associated with bullying victimization. Behaviors associated with significantly lower bullying victimization were eating breakfast on all of the past 7 days, active $60 \mathrm{~min}$ on 5 or more of the past 7 days, and playing on 1 or more sports teams in the past 12 months. Cyberbullying in the past 12 months was also significantly greater across the mental health, substance use, sexual behavior, weight, and asthma variables, again more so for the mental health variables. Playing video games $3+$ hours per day was also positively associated with cyberbullying victimization. Behaviors associated with significantly lower cyberbullying victimization were eating breakfast on all of the past 7 days and active $60 \mathrm{~min}$ on 5 or more of the past 7 days. Contrary to being bullied on school property, cyberbullying victimization was not associated with playing on 1 or more sports teams in the past 12 months.

The frequency of mental health issues (0 through 5) was positively associated with both being bullied on school property in the past 12 months and being cyberbullied in the past 12 months for both males and females (Fig. 2). In a regression model, frequency of mental health issues was regressed on a new variable (both
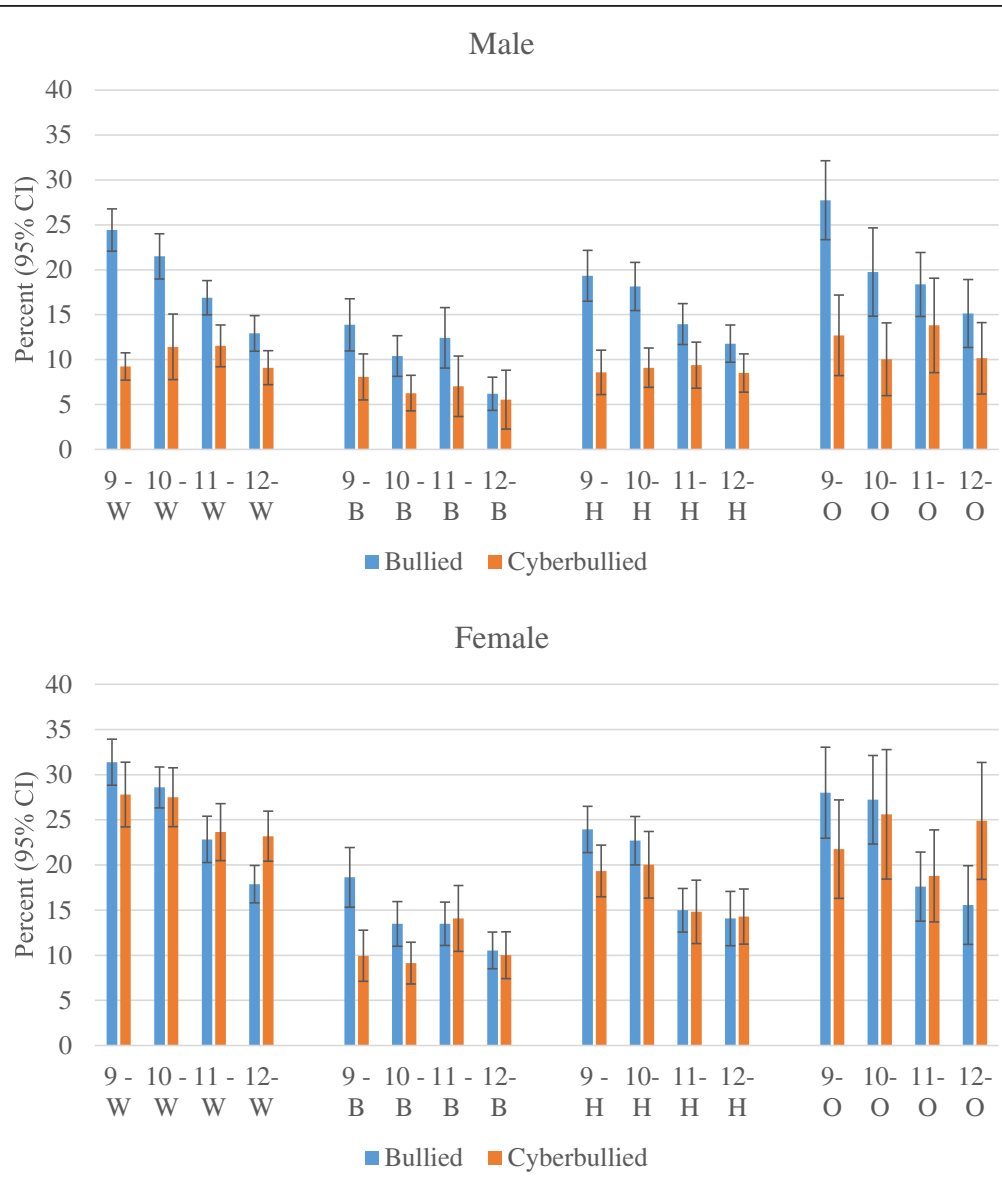

Fig. 1 Bullied on school property or cyberbullied by sex, school grade, and race/ethnicity (White [W], Black [B], Hispanic [H], Other [O]) 
Table 2 Bullying Victimization According to School Grade and Age

\begin{tabular}{|c|c|c|c|c|c|c|c|c|}
\hline Grade & Age & Weighted No. & Weighted \% & Bullied \% & $95 \% \mathrm{Cl}$ & Cyber-bullied \% & $95 \% \mathrm{Cl}$ & Bullied to Cyber-bullied Ratio \\
\hline \multirow[t]{7}{*}{ 9th } & 12 year or younger & 43 & 0.09 & 0.06 & $0.01-0.10$ & 0.06 & $0.00-0.14$ & 1.00 \\
\hline & 13 years & 151 & 0.32 & 0.08 & $0.02-0.15$ & 0.06 & $0.00-0.14$ & 1.33 \\
\hline & 14 years & 17895 & 38.27 & 10.34 & $9.48-11.20$ & 6.12 & $5.31-6.93$ & 1.69 \\
\hline & 15 years & 24641 & 52.69 & 12.58 & $11.55-13.61$ & 8.37 & 7.34-9.39 & 1.50 \\
\hline & 16 years & 3598 & 7.69 & 1.26 & $0.97-1.55$ & 0.99 & $0.67-1.31$ & 1.27 \\
\hline & 17 years & 326 & 0.70 & 0.18 & $0.09-0.27$ & 0.11 & $0.01-0.21$ & 1.64 \\
\hline & 18 years or older & 112 & 0.24 & 0.05 & $0.00-0.11$ & 0.07 & $0.00-0.16$ & 0.71 \\
\hline \multirow[t]{6}{*}{ 10th } & 13 year or younger & 26 & 0.06 & 0.03 & $0.00-0.06$ & 0.03 & $0.00-0.07$ & 1.00 \\
\hline & 14 years & 141 & 0.32 & 0.13 & $0.00-0.26$ & 0.10 & $0.00-0.23$ & 1.30 \\
\hline & 15 years & 17232 & 39.24 & 8.69 & $7.95-9.43$ & 6.04 & $5.09-6.98$ & 1.44 \\
\hline & 16 years & 23548 & 53.62 & 12.10 & $11.02-13.18$ & 9.39 & $8.17-10.62$ & 1.29 \\
\hline & 17 years & 2710 & 6.17 & 1.02 & $0.74-1.29$ & 0.76 & $0.48-1.04$ & 1.34 \\
\hline & 18 years or older & 257 & 0.58 & 0.06 & $0.01-0.11$ & 0.02 & $0.00-0.05$ & 3.00 \\
\hline \multirow[t]{5}{*}{ 11th } & 14 year or younger & 39 & 0.09 & 0.08 & $0.01-0.14$ & 0.04 & $0.00-0.10$ & 2.00 \\
\hline & 15 years & 181 & 0.44 & 0.07 & $0.01-0.13$ & 0.08 & $0.01-0.14$ & 0.88 \\
\hline & 16 years & 17508 & 42.38 & 7.56 & $6.80-8.33$ & 6.03 & $5.02-7.05$ & 1.25 \\
\hline & 17 years & 21261 & 51.46 & 9.20 & $8.32-10.08$ & 8.60 & $7.71-9.50$ & 1.07 \\
\hline & 18 years or older & 2327 & 5.63 & 0.69 & $0.51-0.87$ & 0.67 & $0.42-0.91$ & 1.03 \\
\hline \multirow[t]{4}{*}{ 12th } & 15 year or younger & 87 & 0.22 & 0.06 & $0.01-0.11$ & 0.13 & $0.04-0.21$ & 0.46 \\
\hline & 16 years & 272 & 0.67 & 0.08 & $0.01-0.14$ & 0.11 & $0.02-0.20$ & 0.73 \\
\hline & 17 years & 17907 & 44.37 & 6.38 & $5.61-7.15$ & 6.13 & $5.24-7.02$ & 1.04 \\
\hline & 18 years or older & 22095 & 54.74 & 7.51 & $6.82-8.20$ & 7.87 & $6.98-8.75$ & 0.95 \\
\hline
\end{tabular}

Data source: Youth Risk Behavior Survey (YRBS), 2013

bullied and cyberbullied, bullied only, cyberbullied only, neither bullied or cyberbullied), adjusting for age, sex, and race/ethnicity. This model estimated the average frequency of mental health issues as $0.21(\mathrm{SE}=0.04)$ for neither bullied or cyberbullied, $0.87(\mathrm{SE}=0.08, p<0.0001)$ for cyberbullied only, 0.72 ( $\mathrm{SE}=0.07, p<0.0001$ ) for bullied only, and 1.38 ( $\mathrm{SE}=0.09, p<0.0001$ ) for both bullied and cyberbullied. The latter three $p$ values indicate that the averages are significantly greater than the average frequency of mental health issues for neither bullied or cyberbullied.

\section{Discussion}

This study identified bullying victimization by selected demographic, personal characteristic, and behavior variables. Differences in types of bullying victimization (bullied on school property and cyberbullied) were also assessed across the variables. Mental health problems associated with bullying and/or cyberbullying victimization were also explored.

Greater risk of being bullied among females than males is consistent with previous studies [39-42]. However, the risk of being cyberbullied compared with bullied on school property was noticeably more pronounced in females, which is also consistent with other research [43, 44]. A large, nationally representative survey conducted in the United States in 2013 found that the higher risk of cyberbullying among females persisted for many types of cyberbullying (i.e., hurtful information on the internet, private information purposely shared on the internet, subject of harassing instant messages, subject of harassing text messages, and subject of harassing e-mails) [44]. Although being bullied on school property generally decreased with later school grades for males and females, cyberbullying remained more constant within each racial/ethnic group. Higher levels of cyberbullying victimization among females may be because they more likely choose to bully other females on an emotional level through indirect means where they can remain anonymous in order to not jeopardize closeness and intimacy in their peer group, which is generally more important for girls than boys [22].

Blacks and Hispanics were the least likely to be bullied, as consistent with results from two large, nationally representative samples in the United States [41, 45]. The latter study found that Blacks were less likely than Whites to be victims of verbal or relational bullying [41]. In another national report compiled in 2013, the 
Table 3 Bullying Victimization According Mental Health, Substance Use, Sexual Behavior, Weight, Selected Behaviors, and Asthma

\begin{tabular}{|c|c|c|c|c|c|c|c|c|c|c|}
\hline & $\%$ & $\begin{array}{l}\text { Bullied among } \\
\text { Cases \% }\end{array}$ & $\begin{array}{l}\text { Bullied among } \\
\text { non-Cases }\end{array}$ & $\begin{array}{l}\text { Cases to non-cases } \\
\text { Bullied Ratio }\end{array}$ & $95 \% \mathrm{Cl}$ & $\begin{array}{l}\text { Cyber-bullied } \\
\text { among Cases \% }\end{array}$ & $\begin{array}{l}\text { Cyber-bullied } \\
\text { among non-Cases }\end{array}$ & $\begin{array}{l}\text { Cases to non-cases } \\
\text { Cyber-bullied Ratio }\end{array}$ & $95 \% \mathrm{Cl}$ & $\begin{array}{l}\text { Bullied to Cyber- } \\
\text { bullied Ratio }\end{array}$ \\
\hline \multicolumn{11}{|l|}{ Mental Health } \\
\hline Sad 2 wks past 12 mos & 28.06 & 33.68 & 14.47 & 2.33 & $2.20-2.46$ & 30.16 & 9.52 & 3.17 & $2.94-3.42$ & 1.21 \\
\hline Considered suicide 12 mos & 15.40 & 39.38 & 16.25 & 2.42 & $2.29-2.56$ & 35.17 & 11.60 & 3.03 & $2.81-3.27$ & 1.19 \\
\hline Made suicide plan 12 mos & 12.31 & 40.53 & 16.93 & 2.39 & $2.27-2.52$ & 35.16 & 12.51 & 2.81 & $2.60-3.04$ & 1.21 \\
\hline Attempted suicide $1+$ times 12 mos & 7.26 & 43.84 & 18.43 & 2.38 & $2.23-2.54$ & 41.66 & 13.64 & 3.05 & $2.83-3.29$ & 1.13 \\
\hline Suicide attempt w/injury 12 mos & 2.30 & 48.87 & 19.63 & 2.49 & $2.26-2.74$ & 47.91 & 15.09 & 3.18 & $2.78-3.63$ & 1.09 \\
\hline \multicolumn{11}{|l|}{ Substance Use } \\
\hline Smoked $1+$ past 30 days & 18.00 & 24.42 & 18.72 & 1.30 & $1.22-1.40$ & 23.86 & 13.50 & 1.77 & $1.60-1.95$ & 1.15 \\
\hline Smoked cigarette before 13 & 10.11 & 26.21 & 19.02 & 1.38 & $1.28-1.49$ & 21.90 & 14.59 & 1.50 & $1.34-1.68$ & 1.24 \\
\hline Had $1+$ drinks past 30 days & 38.84 & 21.31 & 18.60 & 1.15 & $1.07-1.22$ & 20.38 & 12.12 & 1.68 & $1.52-1.86$ & 1.23 \\
\hline Had first drink before 13 & 20.06 & 24.76 & 18.79 & 1.32 & $1.24-1.40$ & 19.41 & 14.78 & 1.31 & $1.22-1.42$ & 1.27 \\
\hline Used marijuana $1+$ times past 30 days & 22.45 & 21.07 & 19.46 & 1.08 & $1.02-1.15$ & 20.68 & 13.86 & 1.49 & $1.37-1.62$ & 1.17 \\
\hline Tried marijuana before 13 & 7.96 & 24.18 & 19.48 & 1.24 & $1.14-1.35$ & 20.28 & 15.03 & 1.35 & $1.21-1.50$ & 1.24 \\
\hline Took steroids $1+$ times in life & 3.33 & 33.73 & 19.42 & 1.74 & $1.56-1.93$ & 32.93 & 14.95 & 2.20 & $1.94-2.50$ & 1.11 \\
\hline \multicolumn{11}{|l|}{ Sexual Behavior } \\
\hline Had sex ever & 46.80 & 19.91 & 19.79 & 1.01 & $0.94-1.07$ & 19.41 & 12.04 & 1.61 & $1.48-1.75$ & 1.26 \\
\hline Had sex before 13 & 5.91 & 23.13 & 19.65 & 1.18 & $1.07-1.30$ & 17.97 & 15.37 & 1.17 & $1.01-1.35$ & 1.28 \\
\hline Had sex with 4+ people in life & 14.72 & 19.61 & 19.90 & 0.99 & $0.92-1.05$ & 22.21 & 14.33 & 1.55 & $1.40-1.71$ & 1.08 \\
\hline Had sex with $1+$ people 3 mos & 34.09 & 19.62 & 19.99 & 0.98 & $0.92-1.05$ & 20.32 & 13.04 & 1.56 & $1.44-1.68$ & 1.19 \\
\hline \multicolumn{11}{|l|}{ Weight } \\
\hline Slightly/very overweight & 29.18 & 24.11 & 18.13 & 1.33 & $1.26-1.40$ & 18.48 & 14.30 & 1.29 & $1.19-1.40$ & 1.29 \\
\hline Trying to lose weight & 45.99 & 22.89 & 17.33 & 1.32 & $1.26-1.38$ & 19.37 & 12.22 & 1.59 & $1.47-1.71$ & 1.27 \\
\hline Fasted to lose weight past 30 days & 11.86 & 34.54 & 17.88 & 1.93 & $1.80-2.07$ & 32.78 & 13.10 & 2.50 & $2.32-2.70$ & 1.14 \\
\hline Took pills to lose weight past 30 days & 5.01 & 35.54 & 19.05 & 1.87 & $1.72-2.02$ & 34.54 & 14.55 & 2.37 & $2.14-2.63$ & 1.11 \\
\hline Vomited to lose weight past 30 days & 4.19 & 37.23 & 19.07 & 1.95 & $1.80-2.12$ & 40.52 & 14.45 & 2.81 & $2.56-3.07$ & 1.02 \\
\hline \multicolumn{11}{|l|}{ Selected Behaviors } \\
\hline Ate breakfast on all of the past 7 days & 37.93 & 18.51 & 21.20 & 0.87 & $0.81-0.94$ & 12.77 & 17.58 & 0.73 & $0.67-0.79$ & 1.31 \\
\hline Active 60 min on $5+$ past 7 days & 48.47 & 18.80 & 20.99 & 0.90 & $0.84-0.96$ & 14.12 & 16.97 & 0.83 & $0.78-0.89$ & 1.28 \\
\hline Watched $3+$ hours of TV average day & 32.57 & 20.36 & 19.65 & 1.04 & $0.98-1.10$ & 14.76 & 15.95 & 0.93 & $0.85-1.01$ & 1.30 \\
\hline Played video games $3+$ hours/day & 31.99 & 22.99 & 18.40 & 1.25 & $1.18-1.32$ & 18.46 & 13.93 & 1.32 & $1.23-1.43$ & 1.28 \\
\hline Played on $1+$ sports teams 12 mos & 57.09 & 19.31 & 20.75 & 0.93 & $0.89-0.98$ & 15.49 & 15.69 & 0.99 & $0.91-1.07$ & 1.28 \\
\hline \multicolumn{11}{|l|}{ Asthma } \\
\hline Told by doctor/nurse they had asthma & 21.97 & 23.87 & 18.80 & 1.27 & $1.21-1.34$ & 19.80 & 14.34 & 1.38 & $1.26-1.51$ & 1.25 \\
\hline
\end{tabular}



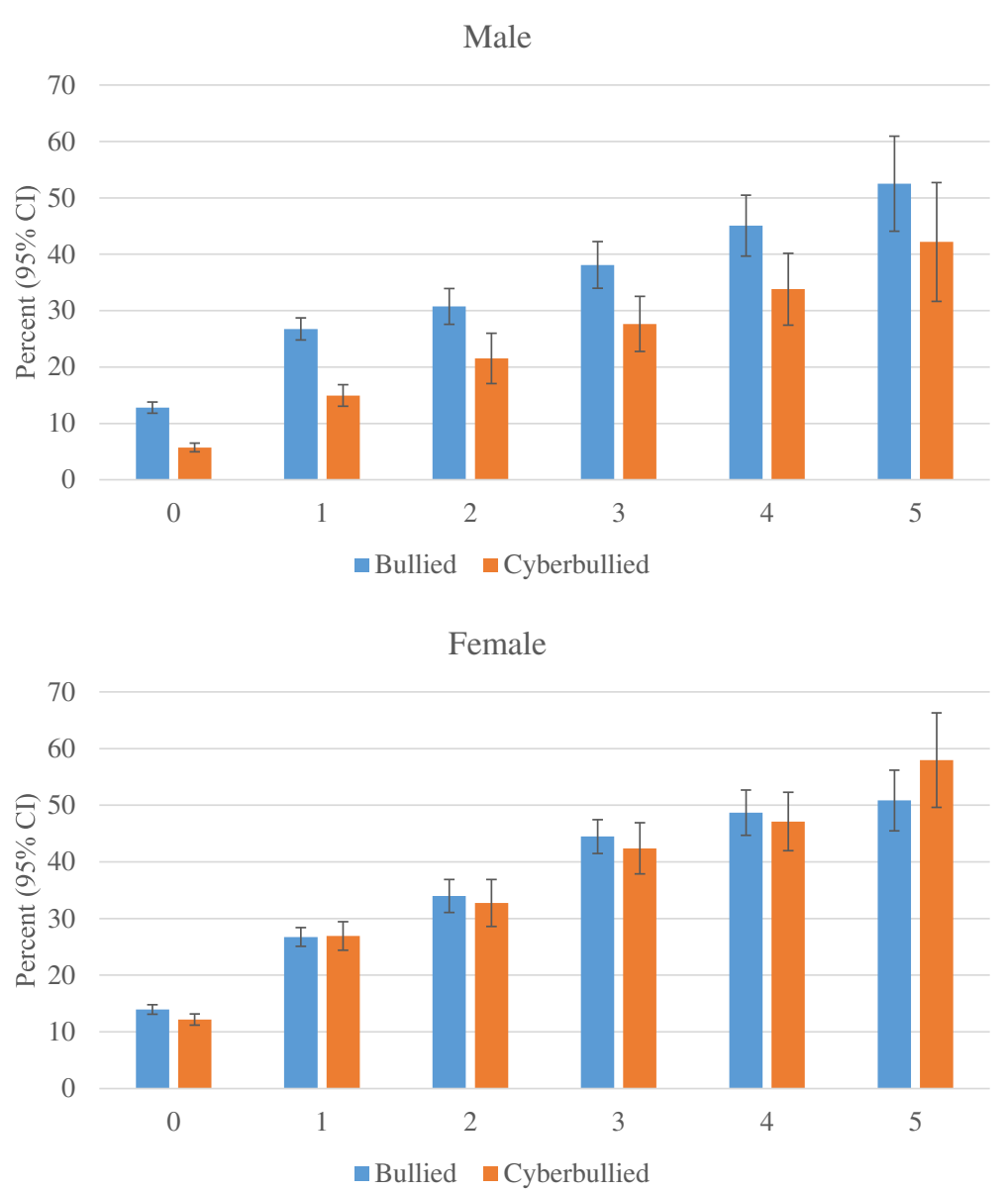

Fig. 2 Bullied or cyberbullied by frequency of mental health issues and sex

frequency of students aged 12-18 who indicated being bullied during the school year was $24 \%$ for Whites, $20 \%$ for Blacks, $19 \%$ for Hispanics, and $9 \%$ for Asians [43]. It may be that Blacks, Hispanics, and Asians are less willing than Whites to be victimized or appear less vulnerable. Further, being bullied on school property was more common than cyberbullying for each of the racial/ethnic groups, although more so for Blacks and Hispanics. This is consistent with lower levels of Internet and computer use among Blacks and Hispanics than Whites or Asians [46].

Previous research has also identified a decrease in traditional bullying victimization with increasing age and school grade [47-51]. Studies have shown that bullying victimization (primarily physical forms) peak at the end of middle school and the beginning of ninth grade, but decline thereafter [51-54]. Two possible reasons for the decrease are that younger children have more children around who might bully them, and the social skills of possible victims of bullies improves as they get older [55]. In contrast, other research has shown that verbal and cyberbullying increases between ages 11 and 15
[56, 57], which is consistent with an increase in cell phone and internet-use in this age range [58]. The students in our study began in grade 9, who were mostly 15 years of age. From grade 9 through 12 we observed a fairly constant level of cyberbullying.

Older children in each school grade were least likely to be victims of bullying, which is again consistent with their having better social skills to better avoid being bullied [55]. On the other hand, younger children in each school grade were also less likely to be victims of bullying. It may be that younger students in a school grade are there because they are better students, have more supportive parents, and generally more connected with their teachers. Research has shown that adolescents with a higher level of school connectedness are at lower risk for bullying victimization $[59,60]$. Adolescents who feel more connected with their school and have parents that are connected with the school are less likely to be victims of bullying [61-63].

We observed that the occurrence and frequency of being bullied and/or cyberbullied was positively associated with feelings of sadness and consideration or 
attempts of suicide. An association between bullying victimization and mental health problems has been observed previously in several studies [64-68]. Being cyberbullied was more strongly associated with the selected mental health problems than being bullied on school property, perhaps because victims of cyberbullying are less likely aware of their bully and feel more helpless against indirect bullying.

Some people are more likely to be bullied simply because they represent an easier option for bullying than if they belonged to the mainstream group [69]. In addition, such individuals may be less understood and viewed as different [70, 71]. For example, there are several examples where students are more likely bullied if their religious practices are less understood (e.g., Muslim girls wearing head scarves, Sikh boys wearing turbans, and Jewish boys wearing yarmulkes) [72]. Anti-Muslim and anti-Sikh bullying has increased in recent years as these groups have been linked with terrorism [72]. In a similar manner, students who use substances, who are sexually active, who have weight problems, or asthma, may be bullied simply because their behaviors or conditions are not widely accepted or understood, or because they appear more vulnerable.

Eating breakfast every day, being physically active, and playing on sports teams was associated with lower victimization from bullying. These behaviors are consistent with social norms that reflect better health, group protection, and lower vulnerability. On the other hand, playing video games an average of 3 or more hours per day was associated with increased risk of being bullied. These students may appear more vulnerable and prone to bullying because they are less likely to be involved in protective behaviors such as participating in sports or being connected to school. It may also be that they have less parental supervision. Data in the current study do not allow us to fully explain this result, but research has shown that lower parental education and broken families are associated with lower family income and less supervision, which, in turn, increase the risk of being bullied [73, 74]. Not living with a mother or father may also reflect a history of greater family conflict and less family attachment, which have further been shown to be associated with increased risk of being a victim of bullying [75].

Being a victim of bullying at school compared with cyberbullying was higher across the mental health (9-21\%), substance use (11-27\%), sexual behavior (8-28\%), weight (2-29\%), other behavior (28-31\%), and asthma (25\%) variables shown in Table 3 . Yet the strength of the association (risk ratio) was generally greater between these variables and cyberbullying victimization. Therefore, although the variables tended to have a stronger association with being cyberbullied, the overall burden of the items was greater for bullying victimization at school because this form of bullying was more common.

The bullying questions used in this study were limited to those available in the YRBS. While the survey is deemed to be valid and reliable, and it is used throughout the United States, the available questions on bullying were limited, not allowing us to tease out specific types of bullying on school property or cyberbullying. In addition, the bullying questions asked about the past 12 months, whereas a shorter time period, such as that past 30 days, could have been more useful. Further, the YRBS survey did not include questions relating to teachers or other school staff members helping with bullying problems, such as feeling comfortable going to a teacher or other school staff member with a concern about bullying victimization.

\section{Conclusion}

Females carry a greater risk of bullying victimization than males. Being bullied on school property decreases with later school grades, but cyberbullying remains constant for males and females within each racial/ethnic group. Maintaining closeness and intimacy in peer groups may be more important in females, causing them to be more likely to choose cyberbullying to remain anonymous. Blacks and Hispanics are less likely to be bullied, possibly because they appear less vulnerable or willing to be victimized. Lower levels of cyberbullying among Blacks and Hispanics corresponds with generally lower Internet and computer use. Occurrence and frequency of being bullied and/or cyberbullied is positively associated with feelings of sadness and consideration or attempts of suicide. Students who use substances, are sexually active, have weight problems, play video games an average of 3 or more hours per day, or have asthma are at greater risk of being bullied, perhaps because they represent an easier option for bullying as they do not belong to the mainstream group. Protective behaviors against bullying victimization include eating breakfast every day, being physically active, and playing on sports teams. These individuals may appear less vulnerable because of better health and group protection. Although being bullied on school property or cyberbullied are associated with greater risk of mental health problems, being both bullied on school property and cyberbullied carries the greatest risk.

\section{Competing interests}

The authors declare that they have no competing interests.

\section{Authors' contributions}

RM conceptualized this work and performed the data analysis and part of the writing. $\mathrm{CH}$ participated in editing and writing sections of the manuscript. Both authors have read and approved the final manuscript. 


\section{Acknowledgements}

Funding for this paper was provided through the Department of Health Science, College of Life Sciences, at Brigham Young University.

Received: 23 May 2015 Accepted: 4 February 2016

Published online: 12 February 2016

\section{References}

1. Hertz MF, Donato I, Wright J. Bullying and suicide: a public health approach. J Adolesc Health. 2013;53(1):S1-3.

2. Juvonen J, Graham S. Bullying in schools: the power of bullies and the plight of victims. Annu Rev Psychol. 2014;65:159-85.

3. Olweus D. Bullying at school: basic facts and effects of a school based intervention program. J Child Psychol Psychiatry. 1994;35(7):1171-90.

4. Smith PK, Cowie H, Ragnar F, Olafsson RF, Liefooghe D. Definitions of bullying: A comparison of terms used, and age and gender differences, in a fourteen-country international comparison. Child Dev. 2002;73(4):1119-33.

5. Maunder RE, Harrop A, Tattersall AJ. Pupil and staff perceptions of bullying in secondary schools: comparing behavioural definitions and their perceived seriousness. Educ Res-Uk. 2010;52(3):263-82.

6. Frisen A, Jonsson AK, Persson C. Adolescents' perception of bullying: who is the victim? who is the bully? what can be done to stop bullying? Adolescence. 2007;42(168):749-61.

7. Espelage DL, Swearer SM. Research on school bullying and victimization: what have we learned and where do we go from here? School Psychol Rev. 2003:32(3):365-83.

8. Nansel TR, Overpeck M, Pilla RS, Ruan WJ, Simons-Morton B, Scheidt P. Bullying behaviors among US youth - prevalence and association with psychosocial adjustment. JAMA. 2001;285(16):2094-100.

9. Lien L, Green K, Welander-Vatn A, Bjertness E. Mental and somatic health complaints associated with school bullying between 10th and 12th grade students; results from cross sectional studies in Oslo, Norway. Clin Pract Epidemiol Ment Health. 2009;5:6.

10. Analitis F, Velderman MK, Ravens-Sieberer U, Detmar S, Erhart M, Herdman $M$, et al. Being bullied: associated factors in children and adolescents 8 to 18 years old in 11 European countries. Pediatrics. 2009;123(2):569-77.

11. Muula AS, Herring P, Siziya S, Rudatsikira E. Bullying victimization and physical fighting among Venezuelan adolescents in Barinas: results from the Global School-Based Health Survey 2003. Ital J Pediatr. 2009:35.

12. Oliveros M, Figueroa L, Mayorga G. Intimidación en colegios estatales de secundaria del Perú. Rev Peru Pediatr. 2009:62(2):68-78.

13. Oliveros M, Figueroa L, Mayorga G. Violencia escolar (bullying) en colegios estatales de primaria en el Perú. Rev Peru Pediatr. 2008;61(4):215-20.

14. Hemphill SA, Kotevski A, Herrenkohl TI, Bond L, Kim MJ, Toumbourou JW, et al. Longitudinal consequences of adolescent bullying perpetration and victimisation: a study of students in Victoria, Australia. Crim Behav Ment Heal. 2011;21(2):107-16.

15. Cook CR, Williams KR, Guerra NG, Kim TE, Sadek S. Predictors of bullying and victimization in childhood and adolescence: a meta-analytic investigation. School Psychol Quart. 2010;25(2):65-83.

16. Wang J, lannotti RJ, Luk JW. Bullying victimization among underweight and overweight U.S. youth: differential associations for boys and girls. J Adolesc Health. 2010;47(1):99-101.

17. Hawker DSJ, Boulton MJ. Twenty years' research on peer victimization and psychosocial maladjustment: a meta-analytic review of cross-sectional studies. J Child Psychol Psyc. 2000:41(4):441-55.

18. Boulton MJ, Trueman M, Flemington I. Associations between secondary school pupils' definitions of bullying, attitudes towards bullying, and tendencies to engage in bullying: age and sex differences. Educ Stud. 2002; 28(4):353-70.

19. Wolke D, Woods S, Stanford K, Schulz H. Bullying and victimization of primary school children in England and Germany: prevalence and school factors. Brit J Psychol. 2001;92:673-96.

20. Card NA, Stucky BD, Sawalani GM, Little TD. Direct and indirect aggression during childhood and adolescence: a meta-analytic review of gender differences, intercorrelations, and relations to maladjustment. Child Dev. 2008:79(5):1185-229

21. Tokunaga RS. Following you home from school: a critical review and synthesis of research on cyberbullying victimization. Comput Hum Behav. 2010;26(3):277-87.
22. Ybarra ML, Mitchell KJ. Youth engaging in online harassment: associations with caregiver-child relationships, Internet use, and personal characteristics. J Adolesc. 2004;27:319-36.

23. Ronning JA, Sourander A, Kumpulainen K, Tamminen T, Niemela S, Moilanen I, et al. Cross-informant agreement about bullying and victimization among eight-year-olds: whose information best predicts psychiatric caseness 10-15 years later? Soc Psych Psych Epid. 2009;44(1):15-22.

24. Schafer M, Korn S, Smith PK, Hunter SC, Mora-Merchan JA, Singer MM, et al. Lonely in the crowd: recollections of bullying. Brit J Dev Psychol. 2004;22: 379-94.

25. Kaltiala-Heino R, Rimpela M, Rantanen P, Rimpela A. Bullying at school - an indicator of adolescents at risk for mental disorders. J Adolescence. 2000; 23(6):661-74.

26. Borowsky IW, Taliaferro LA, McMorris BJ. Suicidal thinking and behavior among youth involved in verbal and social bullying: Risk and protective factors. J Adolesc Health. 2013;53:S4-S12.

27. Kumpulainen $\mathrm{K}$, Rasanen $\mathrm{E}$, Henttonen I, Almqvist F, Kresanov K, Linna S, et al. Bullying and psychiatric symptoms among elementary school-age children. Child Abuse Neglect. 1998;22(7):705-17.

28. Glew G, Rivara F, Feudtner C. Bullying: children hurting children. Pediatri Rev. 2000;21(6):183-89.

29. Roth DA, Coles ME, Heimberg RG. The relationship between memories for childhood teasing and anxiety and depression in adulthood. J Anxiety Disord. 2002;16(2):149-64.

30. Crick NR, Ostrov JM, Burr JE, Cullerton-Sen C, Jansen-Yeh E, Ralston P. A longitudinal study of relational and physical aggression in preschool. J Appl Dev Psychol. 2006;27(3):254-68.

31. Brockenbrough KK, Cornell DG, Loper AB. Aggressive attitudes among victims of violence at school. Educ Treatment Child. 2002;25:273-87.

32. Arseneault L, Walsh E, Trzesniewski K, Newcombe R, Caspi A, Moffitt TE. Bullying victimization uniquely contributes to adjustment problems in young children: a nationally representative cohort study. Pediatrics. 2006; 118(1):130-8.

33. Hodges EVE, Perry DG. Personal and interpersonal antecedents and consequences of victimization by peers. J Pers Soc Psychol. 1999;76(4):677-85.

34. Hawkins JD, Catalano RF. Communities that Care: Action for Drug Abuse Prevention. San Francisco: Jossey-Bass; 1992.

35. Centers for Disease Control and Prevention. Methodology of the Youth Risk Behavior Surveillance System — 2013. MMWR 2013;62(No. 1):1-22.

36. 2013 State and Local Youth Risk Behavior Survey (http://www.cdc.gov/ healthyyouth/yrbs/pdf/questionnaire/2013_hs_questionnaire.pdf).

37. Brener ND, Kann L, Shanklin S, Kinchen S, Eaton DK, Hawkins J, et al. Methodology of the Youth Risk Behavior Surveillance System - 2013: Recommendations and reports. MMWR. 2013;62(RR01):1-23.

38. Kann L, Kinchen S, Shanklin SL, Katherine HF, Hawkins J, Harris WA, et al. Youth risk behavior surveillance - United States, 2013. MMWR. 2014;63(4):1-47.

39. Seals D, Young J. Bullying and victimization: prevalence and relationship to gender, grade level, ethnicity, self-esteem, and depression. Adolescence. 2003:38(152):735-47.

40. Crick NR, Nelson DA. Relational and physical victimization within friendships: nobody told me there'd be friends like these. J Abnorm Child Psychol. 2002; 30(6):599-607.

41. U.S. Department of Education, National Center for Education Statistics, Indicators of School Crime and Safety: 2014 (NCES 2015-072), Fig. 11.1;2015.

42. Wang J, lannotti RJ, Nansel TR. School Bullying Among US Adolescents: Physical, Verbal, Relational and Cyber. J Adolesc Health. 2009;45(4):368-75.

43. Holt TJ, Fitzgerald S, Bossler AM, Chee G, Ng E. Assessing the risk factors of cyber and mobile phone bullying victimization in a nationally representative sample of Singapore Youth. Int J Offender Ther Comp Criminol. 2014. doi:10. 1177/0306624X14554852

44. Robers S, Zhang A, Morgan RE, Musu-Gillette, L. Indicators of School Crime and Safety: 2014 (NCES 2015-072/NCJ 248036). National Center for Education Statistics, U.S. Department of Education, and Bureau of Justice Statistics, Office of Justice Programs, U.S. Department of Justice. Washington, DC; 2015. Indicator 11

45. Spriggs AL, lannotti RJ, Nanselm TR, Haynie DL. Adolescent Bullying Involvement and Perceived Family, Peer and School Relations: Commonalities and Differences Across Race/Ethnicity. J Adolesc Health. 2007;41(3):283-93.

46. File, T Computer and internet use in the United States: Population characteristics. https://www.census.gov/prod/2013pubs/p20-569.pdf 
47. Whitney I, Smith P. A survey of the nature and extent of bullying in junior/ middle and secondary schools. Educ Res. 1993;35:3-25.

48. Borg MG. The extent and nature of bullying among primary and secondary schoolchildren. Educ Res. 1999:41(2):137-53.

49. Due P, Holstein BE, Lynch J, Diderichsen F, Gabhain SN, Scheidt P, et al. Bullying and symptoms among school-aged children: international comparative cross sectional study in 28 countries. Eur J Public Health. 2005; 15(2):128-32.

50. Crookston BT, Merrill RM, Hedges S, Lister C, West JH, Hall PC. Victimization of Peruvian adolescents and health risk behaviors: young lives cohort. BMC Public Health. 2014;14

51. Fitzpatrick KM, Dullin AJ, Piko BF. Not just pushing and shoving: school bullying among African American adolescents. J Sch Health. 2007;77(1):16-22

52. Olweus D. Bullying at School. Oxford: Blackwell Publishers; 1993. National Center for Educaiton Statistics. Student Victimiation in U.S. Schools: Results from the 2009 School Crime Supplent to the Naitonal Crime Victimization Survey (http://nces.ed.gov/pubs2012/2012314.pdf).

53. Peskin MF, Tortolero SR, Markham CM. Bullying and victimization among black and Hispanic adolescents. Adolescence. 2006:41(163):467-84.

54. Zaborskis A, Cirtautiene L, Zemaitiene N. Bullying in Lithuanian schools in 1994-2002. Medicina (Kaunas). 2005:41(7):614-20.

55. Smith PK, Madsen KC, Moody JC. What causes the age decline in reports of being bullied at school? Towards a developmental analysis of risk of being bullied. Ed Res. 1999;41(3):267-85.

56. Espelage DL, Meban SE, Swearer SM. Gender differences in bullying: Moving beyond mean level differences. In: Espelage DL, Swearer SM, editors. Bullying in American schools: A social-ecological perspective on prevention and intervention. Mahwah: Erlbaum; 2004. p. 15-35. As cited in Stassen Berger, K. (2007). Update on bullying at school: Science forgotten? Dev Rev, 27(1), 90-126.

57. Archer J, Cote S. Sex differences in aggressive behavior. In: Tremblay RE, Hartup WW, Archer J, editors. Developmental origins of aggression. New York: Guilford Press; 2005. p. 425-43. As cited in Stassen Berger, K. (2007). Update on bullying at school: Science forgotten? Dev Rev, 27(1), 90-126.

58. Madden M, Lehnhart A, Duggan M, Cortesi S, Gasser U. Teens and technology 2013 (http://www.pewinternet.org/2013/03/13/teens-andtechnology-2013/).

59. Glew GM, Fan MY, Katon W, Rivara FP, Kernic MA. Bullying, psychosocial adjustment, and academic performance in elementary school. Arch Pediatr Adolesc Med. 2005:159(11):1026-31.

60. Skues JL, Cunningham EG, Pokharel T. The influence of bullying behaviours on sense of school connectedness, motivation and self-esteem. Aust J Guid Couns. 2005;15(1):17-26.

61. Espelage DL, Hong JS, Rao MA, Thornberg R. Understanding ecological factors associated with bullying across the elementary to middle school transition in the United States. Violence Vict. 2015;30(3):470-87.

62. Brookmeyer KA, Fanti KA, Henrich CC. Schools, parents, and youth violence: a multilevel, ecological analysis. J Clin Child Adolesc. 2006; 35(4):504-14.

63. Karlsson E, Stickley A, Lindblad F, Schwab-Stone M, Ruchkin V. Risk and protective factors for peer victimization: a 1-year follow-up study of urban American students. Eur Child Adoles Psy. 2014;23(9):773-81.

64. Burk T, Edmondson AH, Whitehead T, Smith B. Suicide risk factors among victims of bullying and other forms of violence: data from the 2009 and 2011 Oklahma Youth Risk Behavior Surveys. J Okla State Med Assoc. 2014; 107(6):335-42.

65. Wichstrom L, Belsky J, Berg-Nielsen TS. Preschool predictors of childhood anxiety disorders: a prospective community study. J Child Psychol Psychiatry. 2013;54(12):1327-36.

66. Bowes L, Wolke D, Joinson C, Lereya ST, Lewis G. Sibling bullying and risk of depression, anxiety, and self-harm: A prospective cohort study. Pediatrics. 2014;134(4):E1032-39.

67. Stapinski LA, Araya R, Heron J, Montgomery A, Stallard P. Peer victimization during adolescence: concurrent and prospective impact on symptoms of depression and anxiety. Anxiety Stress Coping. 2015;28(1):105-20.

68. Schneider SK, O'Donnell L, Stueve A, Coulter RW. Cyberbullying, school bullying, and psychological distress: a regional census of high school students. Am J Public Health. 2012;102(1):171-7.

69. RIC Publication. Bullying in a cyber world (Ages 11-13), p. 34;2010.
70. de Oliveira WA, Silva MA, de Mello FC, Porto DL, Yoshinaga AC, Malta DC. The causes of bullying: results from the National Survey of School Health (PeNSE). Rev Lat Am Enfermagem. 2015;23(2):275-82.

71. Khamis V. Bullying among school-age children in the greater Beirut area: risk and protective factors. Child Abuse Negl. 2015;39:137-46.

72. stopbullying.gov. Religion and faith (http://www.stopbullying.gov/at-risk/ groups/\#religion).

73. Wei HS, Lee W. Individual and social network predictors of physical bullying: a longitudinal study of Taiwanese early adolescents. Violence Vict. 2014; 29(4):701-16.

74. Lister C, Merrill RM, Vance D, West JH, Hall PC, Crookston B. Predictors of peer victimization among Peruvian adolescents in the young lives cohort. Int J Adolesc Med Health. 2014;27(1):85-91.

75. Hemphill SA, Tollit M, Kotevski A, Heerde JA. Predictors of traditional and cyber-bullying victimization: a longitudinal study of Australian secondary School students. J Interpers Violence. 2014;0886260514553636:1-24.

\section{Submit your next manuscript to BioMed Central and we will help you at every step:}

- We accept pre-submission inquiries

- Our selector tool helps you to find the most relevant journal

- We provide round the clock customer support

- Convenient online submission

- Thorough peer review

- Inclusion in PubMed and all major indexing services

- Maximum visibility for your research

Submit your manuscript at www.biomedcentral.com/submit 